\title{
An Investigation into the Current Utilisation and Prospective of Renewable Energy Resources and Technologies in Libya
}

\author{
Ahmed M.A. Mohamed ${ }^{1}$, Amin Al-Habaibeh ${ }^{1}$ and Hafez Abdo ${ }^{2}$ \\ ${ }^{1}$ Advanced Design and Manufacturing Engineering Centre \\ ${ }^{2}$ Nottingham business School \\ Nottingham Trent University, Nottingham, UK
}

\begin{abstract}
With the increase in energy demand and the international drive to reduce carbon emission from fossil fuel, there has been a drive in many oil-rich countries to diversify their energy portfolio and resources. Libya is currently interested in utilising its renewable energy resources in order to reduce the financial and energy dependency on oil reserves. This paper investigates the current utilisation and the future of renewable energy in Libya. Interviews have been conducted with managers, consultants and decision makers from different government organisations including energy policy makers, energy generation companies and major energy consumers. The results indicate that Libya is rich in renewable energy resources but in urgent need for a more comprehensive energy strategy and detailed implementation including reasonable financial and educational investment in the renewable energy sector.
\end{abstract}

Keywords: Demand, Energy, Libya, Renewable, Resources.

\section{Introduction}

Many oil-rich countries in Middle East, including Libya, are trying to diversify their economy and reduce their dependency on oil as a source of income and energy generation in order to develop more sustainable and knowledge-based economy. Securing alternative resources of energy and income is becoming critically important for these countries if they wish to maintain the same standard of living for future generations and reduce pollution and Carbon emission of fusel fuel.

The information currently available in the public domain regarding renewable energy in Libya indicates that Libya is rich in solar and wind energy resources. Libya is located in the middle of North Africa with a huge area of $1,759,540 \mathrm{Km}^{2}$ and a long coast of a length of $1,900 \mathrm{Km}$ on the Mediterranean Sea with $88 \%$ of 
its area considered to be desert where there is a high potentiality of solar and wind energy which can be used to generate electricity thermal, photovoltaic and solar energy conversions. Moreover, it has been estimated that every year, each square kilometre $\left(\mathrm{Km}^{2}\right)$ of desert in the Middle East/ North Africa region receives solar energy equivalent to 1.5 million barrels of crude oil [1]. Based on information extracted from data provided by the German Aerospace Centre (DLR) 2007, Figure 1 indicates an average estimation of annual direct normal solar irradiance in Libya in $\mathrm{kWh} / \mathrm{m}^{2}$ per annum.

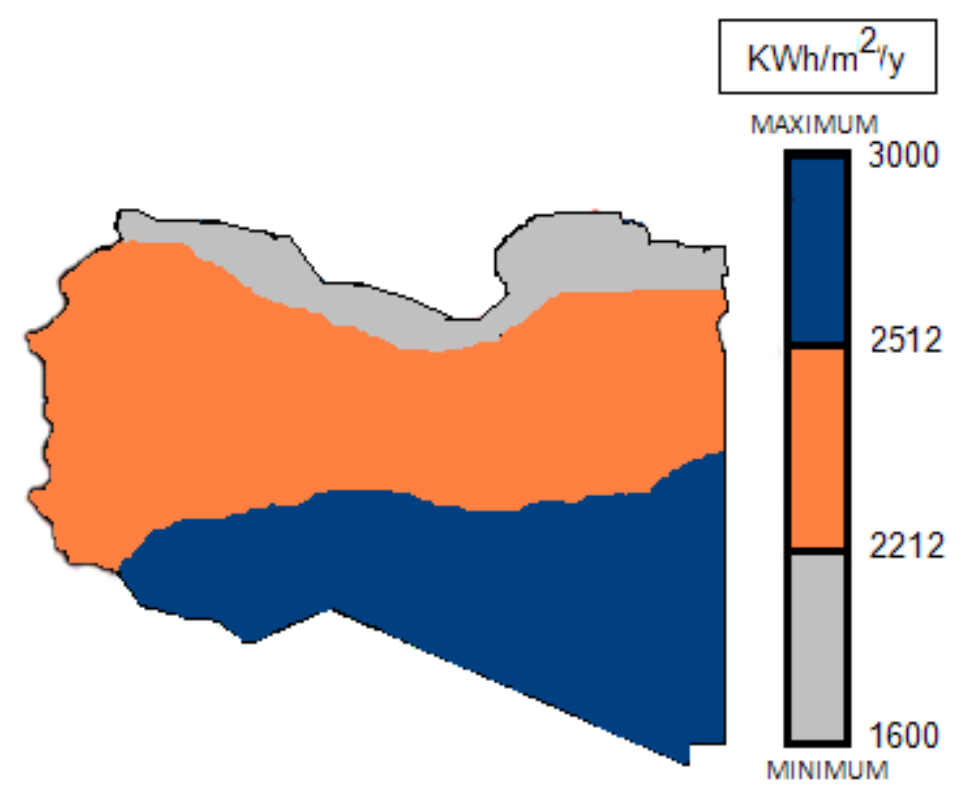

Figure 1: Estimated average solar energy in Libya in $\mathrm{kWh} / \mathrm{m}^{2}$ per annum.

In relation to wind energy resources, the data extracted from Wind Atlas of Libya (version 1.0 March 2008) indicates, as shown in Table 1, the estimated average wind speed in different Libyan cities.

Table 1: The estimated average wind speed in different Libyan cities

\begin{tabular}{|c|c|}
\hline Location & Average of speed \\
\hline Chat & $5.0-5.5 \mathrm{~m} / \mathrm{s}$ \\
\hline Sabah & $6.0-6.5 \mathrm{~m} / \mathrm{s}$ \\
\hline Tarakin & $6.5-7.0 \mathrm{~m} / \mathrm{s}$ \\
\hline Tubruq & $7.0-7.5 \mathrm{~m} / \mathrm{s}$ \\
\hline Al magrun & $7.0-7.5 \mathrm{~m} / \mathrm{s}$ \\
\hline Tukra & $7.0-7.5 \mathrm{~m} / \mathrm{s}$ \\
\hline Jbalzaltan & $7.5-8.0 \mathrm{~m} / \mathrm{s}$ \\
\hline Al-Fattaih- Darnah & $8.0-8.5 \mathrm{~m} / \mathrm{s}$ \\
\hline
\end{tabular}


In general, the average wind speeds ranges between 5 and 10 metres per second in number of the Libyan areas. One of the main advantages of the wind in Libya is that there is a matching between the wind pattern and the pattern of the demand of the electric power in most places [2-4]. Furthermore, Libya is exposed to dry and hot winds which blow several times during the year [5]. In addition, the neighbouring countries to Libya have started to utilise the wind resource with different scales ranging from demonstration projects to commercial size wind farms [6], which is a clear indication of its feasibility in that region.

As far as renewable energy is considered, it is not a well-investigated subject in Libya due to the availability of oil as Libya is one of the leading exporters. Despite the fact that renewable energy such as solar and wind power as discussed above is widely available in Libya, it is still difficult to break the dependency on the oil and natural gas, not only for energy supply but also for revenues to finance the development of the society and the infrastructure.

\section{The problem in Context}

The growth in population is causing significant increase in electricity demand all over Libya which is creating a considerable need for further investment in the infrastructure including power lines and additional power stations. Additionally, the industrial growth is requiring continuous operation of power plants and more fuel consumption. This gives strong demand to study the feasibility and importance of renewable energy in Libya which is the main goal of this paper.

Recent studies have shown that the significance of desert and solar energy as the best alternative to traditional fusel fuel in Libya. However, one of the main renewable energy issues is the degree of matching between load patterns and renewable energy production. However, the demand of energy for airconditioning is one of the main areas for energy consumption which is generally proportional to the availability of solar radiation during the day.

This paper investigates the importance of renewable energy and the possibility of its utilisation in Libya. The characteristic of current energy demand and the availability of renewable energy is discussed based on data provided by several government organisations. Interviews have been conducted with managers, consultants and decision makers from different government organisations including energy policy makers, energy generation companies and major energy 
consumers in order to highlight the potential future of renewable energy sector in Libya.

\section{Methodology}

The Authors have utilised in this paper a combination of different research techniques including field work, secondary data collection and interviews with different stake holders in relation to energy generation and consumption in different organisations in Libya. Secondary documentary data has been collected from several government organisations in order to obtain the necessary information that is related to this subject including policy statements, ministerial or departmental annual reports, legislations, energy sector letters and procedures, have also collected data from several companies such as companies forms and annual reports. The analysis of documentary is essential for initial understanding of the current characteristic of the renewable energy sector. It has been also useful in defining the most appropriate institutions and managers at each level with whom to conduct the interviews for collecting further data and information.

The first author travelled to Libya and visited all the participants for the interviews and for data collection. Unpublished data and information has been collected from different sectors and government organisations and the results are outlined in this paper. Semi-structured interviews have been conducted to develop better understanding of the renewable energy sector. Semi-structured interviews have been selected in this paper because they allow the authors to obtain more details and achieve greater depth of knowledge about what is under investigation, particularly for qualitative and quantitative analysis. In addition, the authors used the interview to study and explore the importance of renewable energy in Libya, current situation of energy generation and consumption in Libya. These interviews are required to uncover specific information from the participants who know and have access to the information being investigated. The field visits to Libya were between January and March 2011 (i.e. before the recent political changes) where the interviews were conducted with 55 participants and lasted between 45 minutes to one hour. The interviewees include the minister of energy, the Chairman of Renewable Energy Authority of Libya, Director of centre for Solar Energy Research and Studies, three directors of local banks and members in the General Planning Council, Director of the General Company for Water Desalination, Director of the General Company for Water Sanitation, faculty deans of Engineering at Tripoli and Benghazi Universities. The interviewees also 
included senior people from General Electricity Company, Gulf Company, Brega Company, Utilisation Sector and others of the various senior managerial levels in Energy Policy Makers (EPM), Energy Generation Companies (EG) and Energy Costuming Companies (EC).

\section{Results and discussion}

The results in this paper will cover the current and future Energy consumption in Libya, the current strategic plans, availability of renewable energy and the perspective of policy makers, energy producers and consumers in relation to the energy sector in Libya.

\subsection{Electrical load variation in Libya}

According to the data obtained from the field visits to Libya, Libya's electric energy demand is expected to grow extremely rapidly. Libyan Energy makers and government organisations expect that demand for electrical power will double by 2014 and it will be more than two and half by the end of the year 2020. Part of this demand could be met by wind energy plants, since wind potential is reasonable in many remote and isolated areas around the country. However, one of the most important tasks which is considered to be the major source of the challenge to the load management engineers in each electrical energy system is electrical load forecasting. The data obtained from Libya during the field work is presented in Figure 2. Based on strategic studies for power electrical demand forecasts and the expansion in production during the period 2011-2015, Figure 2 shows the peak load of the general grid which is 5,964 MW during the period between 2002 and 2011, with annual growth rate of about $10 \%$. 


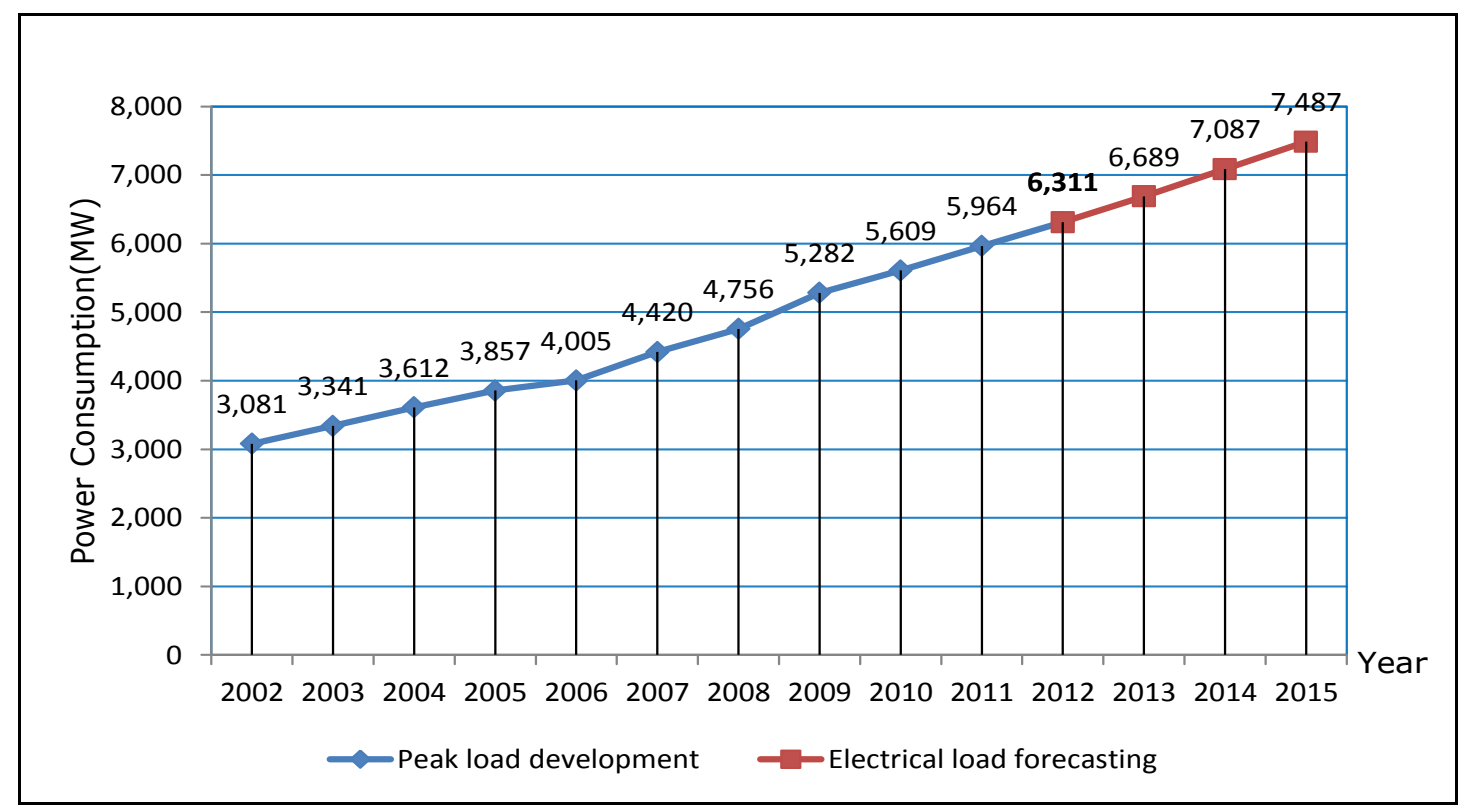

Figure 2: Electrical Peak load development and forecasting.

Many factors included in the load forecasting system which have climatic, political, demographic and economic characteristics. Figure 3 shows the monthly load curves for usual working months for the year 2009. The unpublished data in Figure 3 has been providing by department of the distribution of the eastern regions of General electricity company in March 2011.

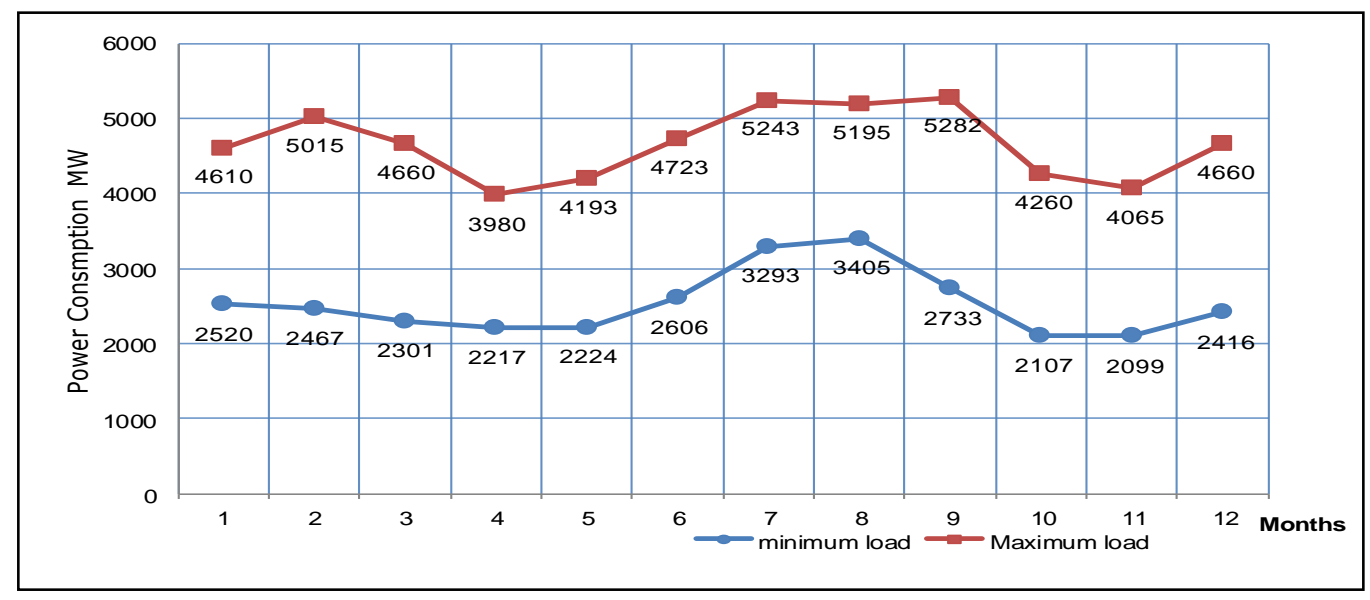

Figure 3: The monthly load as in 2009.

Figure 3 demonstrates the monthly variation of the Libyan electrical load in year 2009, while Figure 4 clarifies the distribution of this load in sector form based on the unpublished data has been collected by the General electricity company in March 2011.The daily and nightly patterns of load variation are similar to each other. An important part of industrial, commercial, public utilises and agriculture loads are mostly daily and nightly loads. The majority of the organisations, official 
departments, educational and academic institutions consume their loads throughout the daytime.

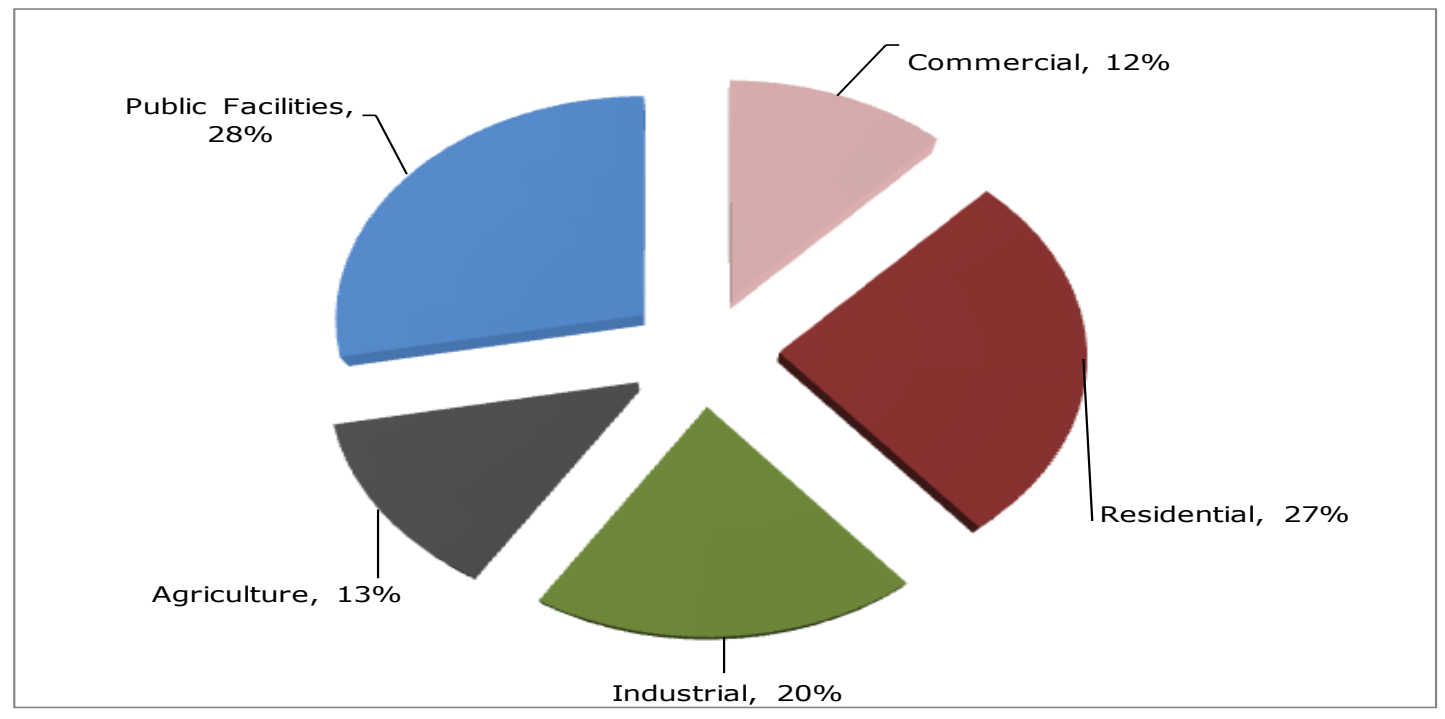

Figure 4: Typical electricity load classification in Libya 2009.

Energy consumption increased steadily over the past years and Libya has Africa's highest electricity generation Per capita consumption which was 4,60 kWh in the year 2009 compared to only 2,65 kWh in the year 2000 as shown in Figure 5 [7].

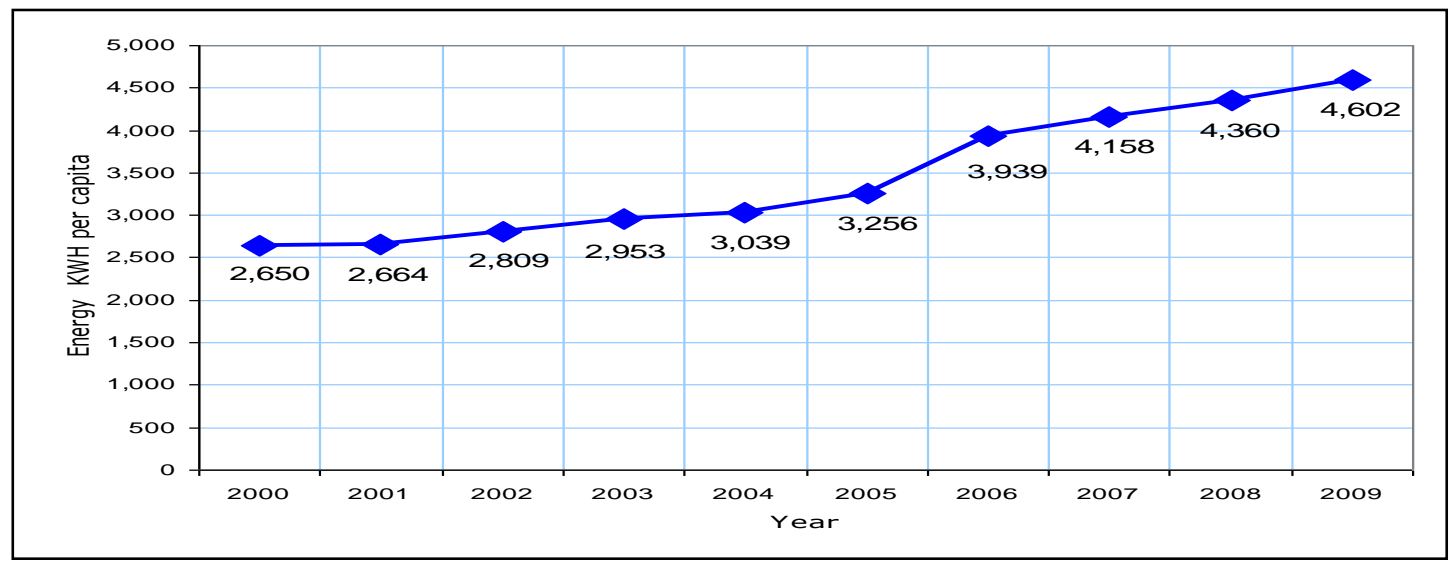

Figure 5: Libya - Electric Power Consumption per capita.

\subsection{Renewable energy in Libya as a Power Supply}

The efforts to introduce a complete or partial alternative to the traditional sources (oil and natural gas) of electrical power are still continuing since 1976, in which the use of photovoltaic systems have started to supply electricity for a cathodic protection station for the oil pipe line connecting Dahra oil field with Sedra Port. In addition, four experimental stations in communication field was installed in 1979. Moreover, in 1983 projects in the field of water pumping was started, 
where water was pumped for irrigation at EL-Agailat by a PV pumping system. The latest project was the construction of Al-Fattaih wind farm at the end of 2010 for production of $60 \mathrm{MW}$ as a first stage of renewable energy development with project cost about 184 Million Libyan Dinar.

One of the main drawbacks of renewable energy is the intermittent nature of these resources. However, many significant achievements have been done in the past few years, which make renewable energy more feasible to use in conjunction with traditional energy resources. The renewable energy role in any country mainly depends on the availability of the resources such as solar radiation, wind, biomass and geothermal. The most suitable way to determine the renewable energy utilisation is the assessment of load variation pattern. Accordingly, it is important to find the extent of matching between the local loads and renewable energy generation schedule. In this regard, it is known that most months are hot in general with a mean temperature of more than $35^{\circ} \mathrm{C}$ and this associated with a high rate of electricity consumption in Libya. Most of the months load consists of water pumps, electric fans and air conditioning. According to the data obtained from the Planning and Studies Department of Renewable Energy Authority in Libya in February 2011, there is a plan for renewable energy sharing with traditional energy to reach $30 \%$ by the year 2030 which mainly includes wind energy, Concentrating Solar Power (CSP), Photovoltaic (PV) and Solar Water Heating (SWH) as shown in Figure 6.

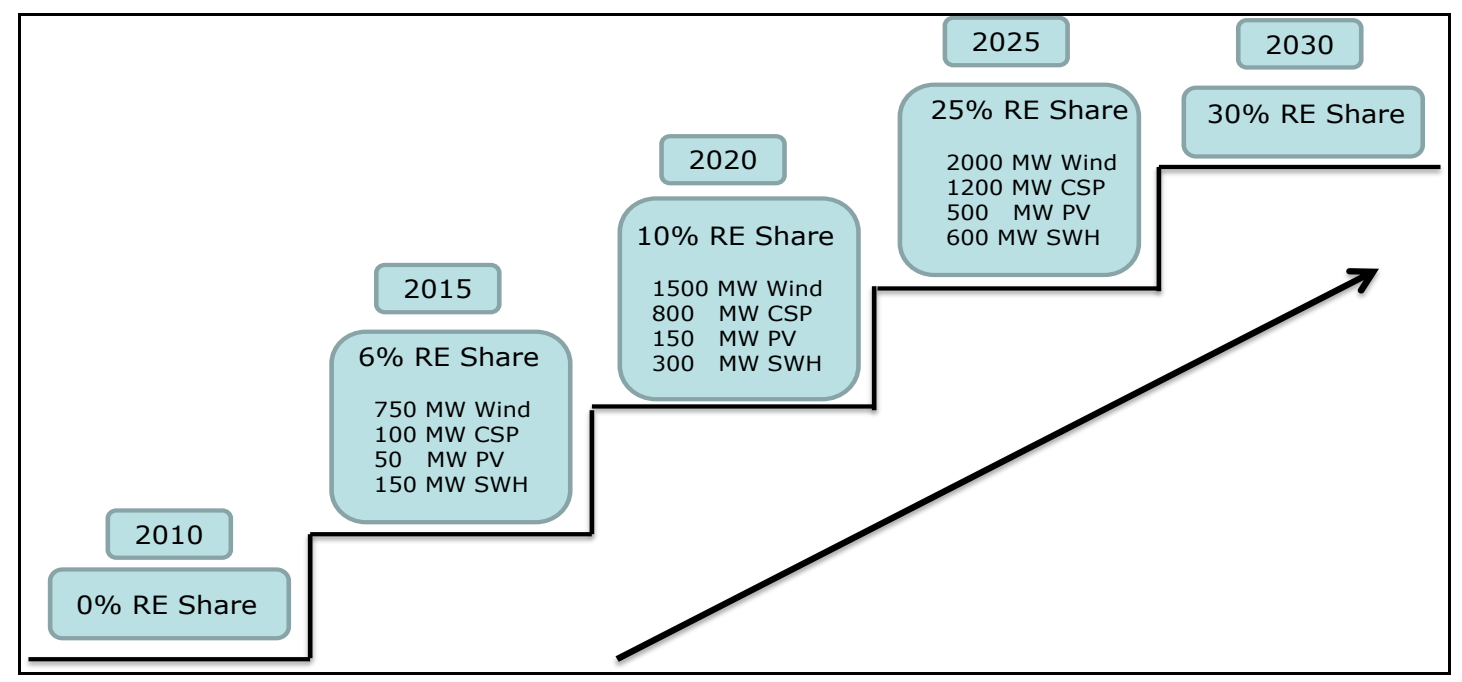

Figure 6: Renewable Energy Sharing plan, data extracted from Planning and Studies Department of Renewable Energy Authority in Libya. 
With regards to the wind energy, it is known that Libya has a long coast, about 1900 kilometres on the Mediterranean sea. In addition, the potential of the wind is reasonable in several regions with an average speed of about $5 \mathrm{~m} / \mathrm{s}$ in most cases, this speed can be harnessed economically. Wind energy could play an important role in the future in order to contribute partially to energy needs and to the total electric energy demand. During the visit to Renewable energy Central Authority of Libya as part of the field work in March 2011, a new wind energy data has been acquired for a period of three months for four stations out of 16 meteorological stations which has been in operation since 2010. Figure 7 shows the average of wind speed in the period between 30/11/2010 and 20/01/2011 recorded each ten second.

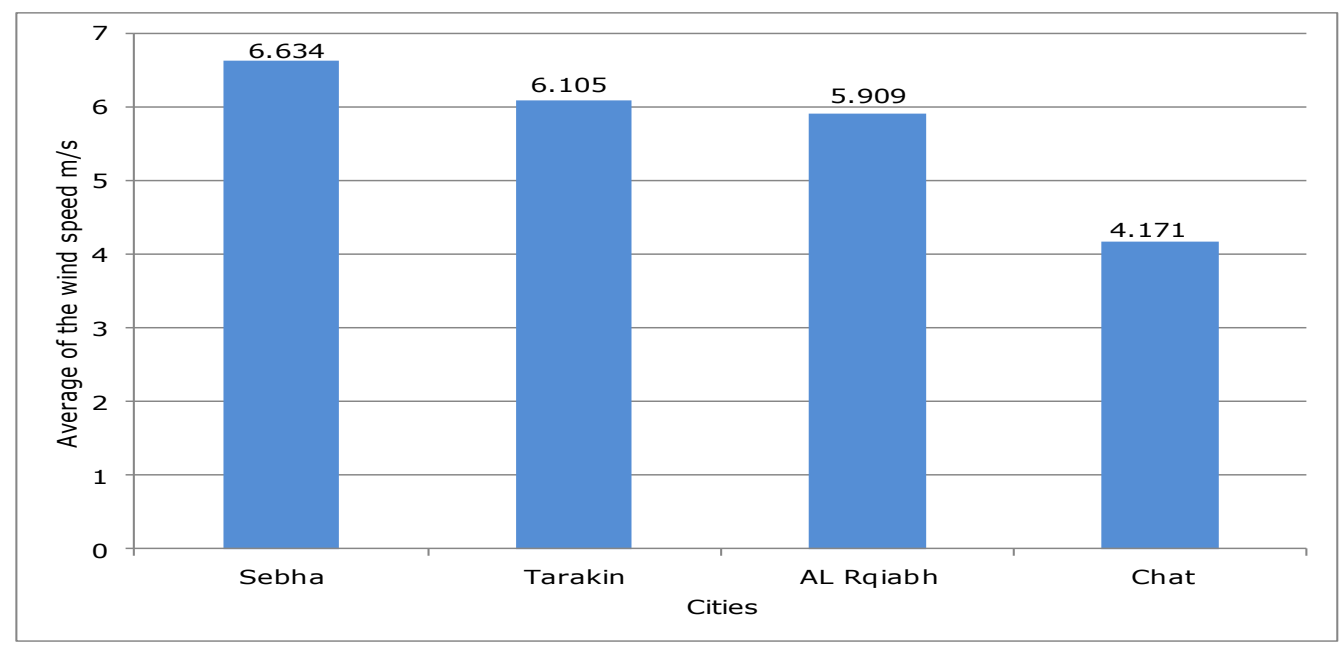

Figure 7: Average of the wind in four cities.

In terms of solar energy, it could be argued that solar energy is the most important renewable energy resource. Based on data acquired from The Centre for Solar Energy Research and Studies, the average annual solar radiation in some areas in Libya is summarised in Figure 8. Solar energy could be considered to be one of the main resources due to the location of Libya on the cancer orbit line with exposure to the sun's rays throughout the year and with long hours during the day. The daily average solar radiation on a horizontal plane is about $7.1 \mathrm{kWh} / \mathrm{m}^{2} /$ day on the coast region in the north and $8.1 \mathrm{kWh} / \mathrm{m}^{2} /$ day in the South region, with the average annual sun duration more than 3500 hours per annum. 


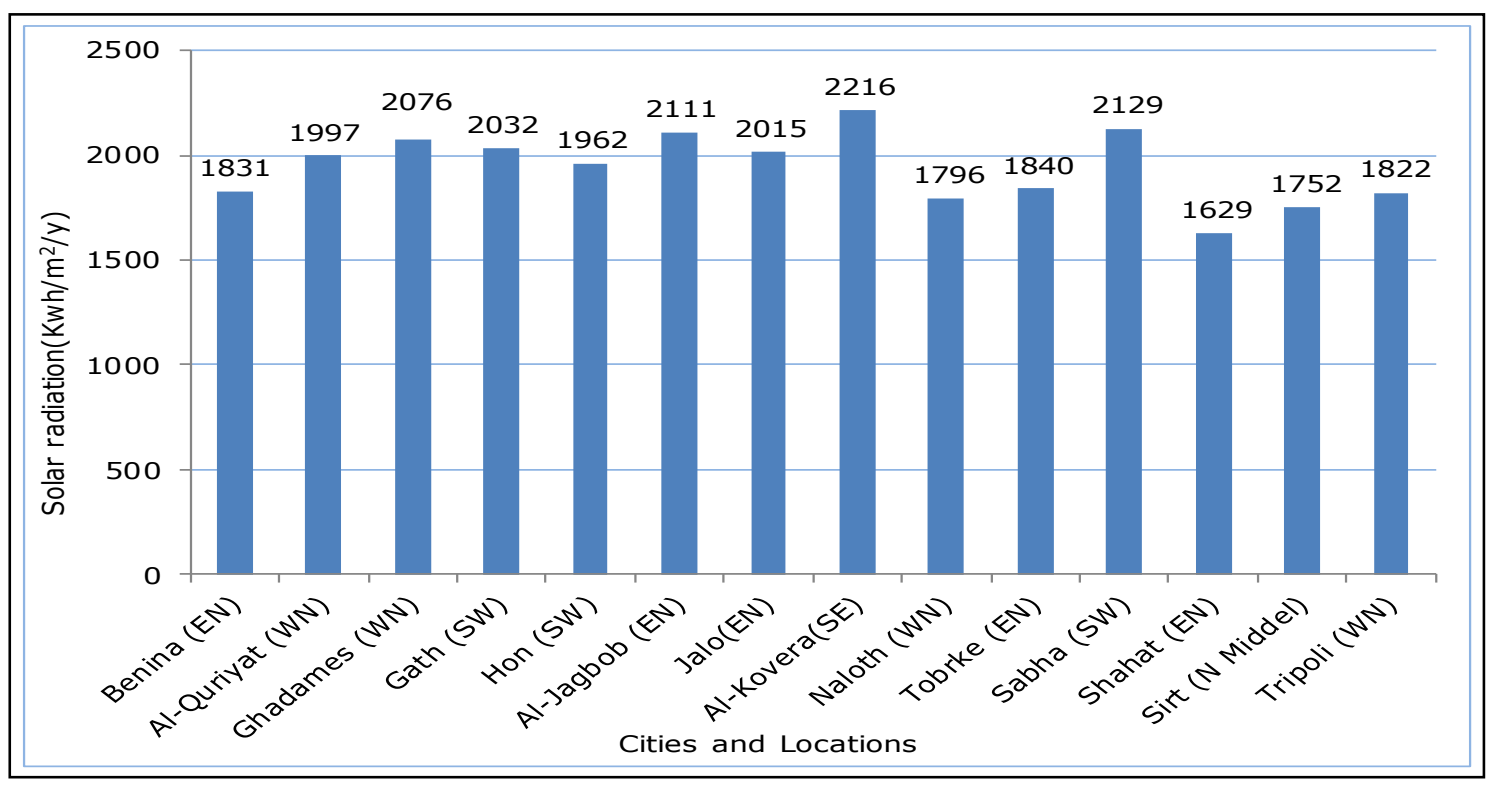

Figure 8: Average annual solar radiation in some areas in Libya.

The renewable energy authority of Libya stated that the average hours of solar brightness is about 3200 hours per year and the average solar radiation is $6 \mathrm{kWh}$ per square meter per day. This will equal $=10^{6} \times 1.5 / 365 \approx 4110$ barrels of oil per days. Therefore, if we use only $0.1 \%$ of Libyan area this would lead to $(0.001$ $\left.\times 1.7 \times 10^{6}\right)$ and this equivalent to $\left(1.7 \times 10^{6} \mathrm{~km}^{2} \times 0.001\right) \times 4110=6.986$ million barrels of oil per day of energy. This number is six times more than the current Libyan production of oil. Therefore, the wind and solar energy could provide a good complement to meet peak loads. And this in turn can be a good reason for encouraging wind and solar energy projects in Libya.

\subsection{Current projects in renewable energy}

The distribution network of electricity in Libya is expensive due to its vast area with about 200 scattered villages with population ranges between 25 and 500 inhabitancies and far away from the grid by not less than $25 \mathrm{~km}$ [8]. The distributed generation is a new important tendency in energy systems, which should be considered as an alternative to traditional energy production. This concept is significant to prevent power failure, which can be avoided if an area does not depend only on one energy resource. Utilisation of renewable energy resource makes distributed systems more feasible due to the fact that energy can be produced closer to the demand centres, decreasing the need for long transmission lines and reducing power loss across those lines. The use of renewable energy resources in its simple form of direct use for heating water 
solar ovens, geothermal heat pumps and mechanical wind turbines, or in its more complicated form of indirect use in creating other energy sources to produce electricity by means of photovoltaic cells and generation through wind turbines, could save the public budget huge funds, as well as providing good service to people, particularly in remote areas.

\section{The Research Interviews}

Table 2 summarised the interviews based on the sector and the organisation with unique code for each interviewee and the geographical location.

$\mathrm{T}$

able 2: Summary of the interviews.

\begin{tabular}{|c|c|c|c|c|}
\hline Classification & $\begin{array}{l}\text { Organisations of } \\
\text { Interviewees list }\end{array}$ & $\begin{array}{c}\text { Code of } \\
\text { Interviewee }\end{array}$ & City & $\begin{array}{l}\text { Number of } \\
\text { Interviews }\end{array}$ \\
\hline \multirow{2}{*}{$\begin{array}{l}\text { Energy } \\
\text { Policy } \\
\text { Makers }\end{array}$} & $\begin{array}{l}\text { Renewable Energy } \\
\text { Authority }(A)\end{array}$ & $\mathrm{A} 1, \mathrm{~A} 2, \ldots \ldots \mathrm{A} 5$ & Tripoli & 5 \\
\hline & $\begin{array}{l}\text { Centre for Solar } \\
\text { Energy Research and } \\
\text { Studies (B) }\end{array}$ & $\mathrm{B} 1, \mathrm{~B} 2, \mathrm{~B} 3, \mathrm{~B} 4$ & Tripoli & 4 \\
\hline \multirow[t]{2}{*}{ E P M } & $\begin{array}{l}\text { Members of General } \\
\text { Planning Council (C) }\end{array}$ & $\mathrm{C} 1, \mathrm{C} 2, \ldots . \mathrm{C} 5$ & Tripoli & 5 \\
\hline & Universities (D) & $\mathrm{D} 1, \mathrm{D} 2, \ldots \mathrm{D} 8$ & Tripoli/Benghazi & 8 \\
\hline \multirow{3}{*}{$\begin{array}{l}\text { Energy } \\
\text { Generation } \\
\text { Companies }\end{array}$} & $\begin{array}{l}\text { General Electricity } \\
\text { Company (E) }\end{array}$ & $\mathrm{E} 1, \mathrm{E} 2, \ldots \mathrm{E} 6$ & Tripoli/ Benghazi & 6 \\
\hline & Breaga Company (F) & $\mathrm{F} 1, \mathrm{~F} 2, \ldots . \mathrm{F} 6$ & Tripoli & 6 \\
\hline & Gulf Company (G) & $\mathrm{G} 1, \mathrm{G} 2, \ldots \mathrm{G} 5$ & Tripoli & 5 \\
\hline \multirow{3}{*}{$\begin{array}{c}\text { Energy } \\
\text { Costuming } \\
\text { Companies }\end{array}$} & $\begin{array}{l}\text { The General Company } \\
\text { for Water Desalination } \\
(\mathrm{H})\end{array}$ & $\mathrm{H} 1, \mathrm{H} 2, \ldots \ldots . \mathrm{H} 10$ & Tripoli/ Benghazi & 10 \\
\hline & $\begin{array}{l}\text { The General Company } \\
\text { for Water Sanitation (I) }\end{array}$ & $\mathrm{I} 1, \mathrm{I} 2, \mathrm{I} 3$ & Tripoli/ Benghazi & 3 \\
\hline & Utilities Sector $(\mathrm{J})$ & $\mathrm{J} 1, \mathrm{~J} 2, \mathrm{~J} 3$ & Tripoli/ Benghazi & 3 \\
\hline \multicolumn{4}{|c|}{ Total } & 55 \\
\hline
\end{tabular}

The authors initiated their methodology by designing a survey, and all the interviews were transcribed, coded, and each code was given a letters and number related to each case. Using computer software, the codes were divided and classified into simple codes to situate them for study. Data and information have been collected from the interviews and analysed in qualitative way which is not for mere counting or providing numeric summaries, but also to discover variation and examine complexities $[9,10]$. In this respect a semi structured interviews approach was used which allowed the dialogue to be exploratory, and unrestrictive. In addition, in order to obtain a more in-depth insight into the subject under study, it was coded and used a new question which is emerged during the interview time. Both the closed questions and open questions were utilised in this interviews which was suitable for questions structured answers for 
simplified coding and analysis. Therefore, the result of the interviews have been summarised based on the classifications in Table 3 to Table 9:

Table 3: Renewable energy is available for commercial utilisation in Libya.

\begin{tabular}{|c|c|c|c|}
\hline \multicolumn{4}{|c|}{$\begin{array}{c}\text { Q A: Do you think renewable energy is available in Libya for commercial } \\
\text { utilisation? }\end{array}$} \\
\hline \multirow{2}{*}{ Sectors } & \multicolumn{3}{|c|}{ Responses } \\
\hline & Yes & NO & $\begin{array}{l}\text { Don't } \\
\text { know }\end{array}$ \\
\hline Energy Policy makers (EPM) & $100 \%$ & 0 & 0 \\
\hline Energy Generation (EG) & $71 \%$ & 0 & $29 \%$ \\
\hline Energy costumers (EC) & $56 \%$ & 0 & $44 \%$ \\
\hline Total \% & $78 \%$ & 0 & $22 \%$ \\
\hline
\end{tabular}

As shown in Table 3, $100 \%$ of the Energy Policy Makers (EPM) think that renewable energy is available in Libya for commercial utilisation. The majority of the Energy Generation $71 \%$ (EG) and about $56 \%$ of Energy Costumers agree that the renewable energy is available. However, none of the interviewees disagreed with the lack of commercial opportunities and $22 \%$ of the respondents lack the information or the knowledge. It is evident that the Energy Policy Makers have more experience and information than the other two sectors. In addition, Energy Generation (EG) thought renewable energy resources will have a huge effect on their functions and many users will lose their business. Therefore, the results of question QA agree with the previous literature review of this paper, such as Franz Trieb [1] and Atlas of Libya measurement [11].

It was clear from the interviews that there is some resistance from the energy generation sector to renewable energy as stated by one of the interviewees:

....Many functions in the General Electricity Company will be redundant if discovery and utilisation of the renewable energy is done ....(EGE1)

Lack of confidence from the consumer market is also reflected by one of the interviewees:

...... Many of the projects begins strongly but sometimes are stopped or cancelled for example the Train project (ECH1) 
Another respondent also said:

any new projects will increase the range of the tax therefore Libya at this time does not need any other projects. The Great Man-Made River resulted in a tax of 20 dirhams per litre on petrol, quarter dirhams on domestic gas cylinders, about half a dinar a litre of engine oil, airline tickets, tariff and currency exchange, etc. (EC $\left.\mathrm{E}_{\mathrm{I} 1}\right)$

As referred to director of Centre for Solar Energy Research and Studies:

..... it's important to inform you that, there is no need to clear up the solar flat in Libya's desert due to the dryness and the size of the dust particles .(EPMA1)

On a similar line of query, participants were asked a question regarding the importance of renewable energy in Libya as shown in Table 4.

Table 4: The importance of renewable energy to the development of Libya.

Q B: Do you think renewable energy is important to the development of Libya?

\begin{tabular}{|c|c|c|c|}
\hline \multirow{2}{*}{ Sectors } & \multicolumn{3}{|c|}{ Responses } \\
\cline { 2 - 4 } & Yes & No & $\begin{array}{c}\text { Don't } \\
\text { know }\end{array}$ \\
\hline Energy Policy makers (EPM) & $91 \%$ & $9 \%$ & 0 \\
\hline Energy Generation(EG) & $82 \%$ & $12 \%$ & $6 \%$ \\
\hline Energy costumers (EC) & $88 \%$ & $13 \%$ & 0 \\
\hline Total \% & $87 \%$ & $11 \%$ & $2 \%$ \\
\hline
\end{tabular}

As shown in Table 4, $87 \%$ of respondents believe that renewable energy will play an important role in economy and environrment in libya in the future. However, $9 \%$ of the (EPM companies), $12 \%$ of the (EG companies) and $13 \%$ of the (EC companies) do not believe that. On the other hand $6 \%$ of (EG companies) indicated that they don't know. This result confirms what has been mentioned in the theoretical part which is the importance of the renewable energy to economy development, and this was clear from several interviewees:

.... Libyans should admit that it's important to support the economy with renewable resources,......... to maintain the standard of living and facing the country's growing demands for energy not only for energy supply but also for 
financial revenues, sustaining the public budget as well as providing good service to the people in scattered villages and countryside areas ......(EPMA1)

Another interview from General Planning Council said:

There is no scientific studies, academic research or feasibility studies by economic decision makers to indicate that there is any obstacles in utilising renewable energy (EPMC1)

As referred to by one of the Centre for Solar Energy Research and Studies:

Libya has a huge area and a long coast and solar and wind energy has the potential be harnessed economically, but currently is no suitable businesses or projects available in order to utilise these resources (EGF3)

Energy generation manager stated that:

The discovery of new source of energy will have no impact on the economy of Libya due to exporting of oil since 196, it is considered to be one of the largest sources of income. It is unlikely that renewable energy will have significant impact during the current period on the economy, but it is expected to have some negative effect on the environment .(EG $(E 3)$

Table 5: Renewable energy will satisfy energy demand following the expiration of oil.

Q C: Do you think renewable energy will satisfy energy demand following the expiration of oil ?

\begin{tabular}{|c|c|c|c|}
\hline \multirow{2}{*}{ Sectors } & \multicolumn{3}{|c|}{ Responses } \\
\cline { 2 - 4 } & Yes & No & $\begin{array}{c}\text { Don't } \\
\text { know }\end{array}$ \\
\cline { 2 - 4 } & $82 \%$ & 0 & $18 \%$ \\
\hline Energy Policy makers (EPM) & $59 \%$ & $12 \%$ & $29 \%$ \\
\hline Energy Generation (EG) & $56 \%$ & $6 \%$ & $38 \%$ \\
\hline Total \% & $67 \%$ & $5 \%$ & $27 \%$ \\
\hline
\end{tabular}

As indicated in Table 5, 67\% believed that renewable energy will satisfy energy demands after the expiration of oil, $5 \%$ of respondents however, think not and $27 \%$ lack the knowledge and information with regards to the ability, and capacity of renewable energy which will be the best alternative. It was felt that consumers 
and producers of energy have limited confidence or knowledge regarding the capability of renewable energy. This was clear from an interviewed manager from the Energy Generation sector who stated that:

we have no data about the costs of renewable energy in the future, it's not a well important matter in this time due to the availability of oil.......about the environment issue and energy demand after the oil ..........renewable energy is the best source of energy environmentally and economically; but its utilisation in Libya is still in the early days ......(EGe3)

Table 6: Type of renewable energy with highest feasibility.

Q D: Which type of renewable energy do you think has the most potential and could become the most economically feasible for large-scale use ?

\begin{tabular}{|c|c|c|c|c|c|}
\hline \multirow{2}{*}{ Sectors } & \multicolumn{5}{|c|}{ Responses } \\
\cline { 2 - 6 } & Biomass & Geothermal & Wind & $\begin{array}{c}\text { wave } \\
\text { and } \\
\text { tidal }\end{array}$ & Solar \\
\hline Energy Policy makers (EPM ) & 0 & 0 & $32 \%$ & $23 \%$ & $45 \%$ \\
\hline Energy Generation(EG) & 0 & 0 & $35 \%$ & $18 \%$ & $47 \%$ \\
\hline Energy costumers(EC) & 0 & 0 & $38 \%$ & $13 \%$ & $50 \%$ \\
\hline Total \% & 0 & 0 & $35 \%$ & $18 \%$ & $47 \%$ \\
\hline
\end{tabular}

Table 6 indicates that $47 \%$ believe solar is the dominant technology for the future followed by wind energy (35\%) and wave and tidal (18\%). This is consistent with the location of Libya in which huge desert with exposure to the sun radiation throughout the year. With regard to Biomass and Geothermal it is still unusual and also this is consistent with the nature of the Libyan desert with a shortage of arable land, animals and the small population. This was clear from an interviewed manager of Energy Policy Maker who stated that:

I believe that the solar energy will be the main source of energy in its small or/and large-scale form in scattered villages which is far away from the grid ... I confirm that it is the best solutions (EPM $\left.M_{D 2}\right)$ 
Another interviewee said:

the importance of the use renewable energy in Libya in its different ways and forms not for energy supplying Libya only.... but also for helping other countries such European and Africa countries (EPM $\left.M_{B 1}\right)$

Another respondent said:

the utilisation of renewable energy in Libya on Large-scale could result in diversifying the sources of energy and creating new employment opportunities .....(EGE3)

Table 7: Energy sector that has the best investment opportunities.

Q E: What energy sector do you think could have the best investment opportunities?

\begin{tabular}{|c|c|c|}
\hline \multirow{2}{*}{ Sectors } & \multicolumn{2}{|c|}{ Responses } \\
\cline { 2 - 3 } & $\begin{array}{c}\text { Oil and Natural } \\
\text { Gas }\end{array}$ & $\begin{array}{c}\text { Renewable } \\
\text { Energy }\end{array}$ \\
\hline Energy Policy makers (EPM ) & $45 \%$ & $55 \%$ \\
\hline Energy Generation (EG) & $41 \%$ & $59 \%$ \\
\hline Energy Costumers(EC) & $75 \%$ & $25 \%$ \\
\hline Total \% & $53 \%$ & $47 \%$ \\
\hline
\end{tabular}

As presented in Table 7, about $47 \%$ of interviewees believe that the renewable energy will be the best field for investment. On the other hand $53 \%$ of interviewees think fossil fuel such as oil and natural gas where the investment should be. The later seems to have lack of knowledge and information about the details of investment, an interviewee of Energy Costumers who stated that:

I think, it is still early to compare between these resources due to cost, risk and safety.......We use traditional source with high level of confidence and reliability which is still cheaper than other sources ......(EC $\left.C_{H 1}\right)$

Another interviewee said:

indeed, it might not need second thought to invest in oil and neutral gas companies ..... on the other hand, it would need more time to think about other investments ........(E. $\left(\mathrm{EC}_{\mathrm{H} 3}\right)$ 
As referred to by one manager at the Centre for Solar Energy Research and Studies:

We should utilise every source of energy and support the local and foreign investors to enter the Libyan's market. Additionally, we still need improving the infrastructure of the country such as the road network and investment laws to attract investors... (EPM $B 3)$

Table 8: The reasons behind the insufficient electricity production to meet demand.

\begin{tabular}{|c|c|c|c|c|}
\hline \multirow[b]{2}{*}{ Sectors } & \multicolumn{4}{|c|}{ Responses } \\
\hline & $\begin{array}{l}\text { Productive } \\
\text { capacity } \\
\text { of stations }\end{array}$ & $\begin{array}{l}\text { Increasing } \\
\text { energy } \\
\text { demand }\end{array}$ & $\begin{array}{l}\text { The size } \\
\text { of grid }\end{array}$ & $\begin{array}{l}\text { Other } \\
\text { technical } \\
\text { problems }\end{array}$ \\
\hline Energy Policy makers (EPM ) & $18 \%$ & $41 \%$ & $14 \%$ & $27 \%$ \\
\hline Energy Generation (EG) & $18 \%$ & $47 \%$ & $18 \%$ & $18 \%$ \\
\hline Energy Costumers (EC) & $31 \%$ & $38 \%$ & $31 \%$ & 0 \\
\hline Total \% & $22 \%$ & $42 \%$ & $20 \%$ & $16 \%$ \\
\hline
\end{tabular}

Table 8 indicates that the insufficient electricity production to meet demand is caused $64 \%$ by the increase in demand with limited production capacity from power stations. However, $16 \%$ indicated other maintenance and technical problems and $20 \%$ indicated the effect of the size of the grid. It was evident that demand has been growing much faster than the production capacity in place.

One of the interviewees from the energy generation sector stated that:

Currently, Libya's energy network consists of approximately 13,000 miles of $66-\mathrm{kV}$ and $30 \mathrm{kV}$ lines and 8,000 miles of 220-kV lines which does not cover all the Libyan scattered villages...... and long distance would require periodic maintenance...... (EG $\left.G_{E 6}\right)$

Another interviewee stated that:

I expect that electrical consumption will double in the coming years (EPM $\mathrm{c2}$ ). 
Another interviewee stated:

I believe that it's impossible to increase the production capacity of the power stations due to many reasons such as most energy plants require an urgent maintenance and upgrading ..(EGE3)

Another interviewee stated:

...Libya's energy sector requires crucial investment. General Electricity Company has suggested that it may allow private investment in Libya's generation and distribution sectors to be able to meet the demand (EGE1)

Table 9: Adequate effort was done to promote renewable energy by Libyan government.

Q G: Do you think that adequate effort was done to promote renewable energy by the Libyan government?

\begin{tabular}{|c|c|c|c|}
\hline \multirow{2}{*}{ Sectors } & \multicolumn{3}{|c|}{ Responses } \\
\cline { 2 - 4 } & Yes & No & $\begin{array}{c}\text { Yes, but more } \\
\text { is needed }\end{array}$ \\
\hline Energy Policy makers (EPM) & $23 \%$ & $14 \%$ & $64 \%$ \\
\hline Energy Generation (EG) & $47 \%$ & $29 \%$ & $24 \%$ \\
\hline Energy Costumers(EC) & $13 \%$ & $50 \%$ & $38 \%$ \\
\hline Total \% & $27 \%$ & $29 \%$ & $44 \%$ \\
\hline
\end{tabular}

In response to government efforts in relation to renewable energy, Table 9 shows that $27 \%$ of interviewees believed that the government has done sufficient effort to promote renewable energy and $44 \%$ of the respondent stated that the Libyan government has promoted renewable energy but more work is still needed. About $29 \%$ of them said NO, Libyan government has not done enough sufficient work to promote renewable energy.

One of the interviewees who believed that the government has done sufficient contribution stated that:

Libyan government has created Renewable Energy Authority and Centre for Solar Energy Research and Studies which are supposed to be responsible for renewable energy development and establishment ......(EPMC1) 


\section{Further results from interviewees}

Most interviewees in the three sectors highlight the importance of the renewable energy resources, with relative differences amongst them. While participants of both energy consumptions (EC) and energy generation (EG) give equal importance to utilise and invest in this field, the energy policy makers (EPM) give more importance compared with EG and EC to renewable energy resources. In general, according to the interviewees, the three sectors aim to achieve three main objectives relative to political, social and environmental as follows:

1) Diversifying the sources of energy.

2) Creating possible new employment opportunities.

3) Preventing environmental pollution.

With regard to the majority of the interviewees in EPM and EG, the following issues have been highlighted:

1) Encouraging local industries and investments related to renewable energy.

2) The need for local training centres associated with renewable energy in order to increase formal education.

3) Current production capacity of energy does not the demand in Libya.

However, the analysis that was identified during the interview could be summarised as follows:

1) The renewable energy can be used for heating water in the domestic water heating, tourist hotels, swimming pools heating and public toilets in urban areas and many facilities in desert roads, which only need between $1 \mathrm{Kw}$ and $1 \mathrm{Mw}$ such as the military points, border points and restaurants.

2) There is a positive public opinion toward renewable energy, the number of the energy conferences and initiatives confirms that.

3) There is a possibility to use the solar energy across Libya, while wind power can be used in specific areas.

4) There is significant support for renewable energy as one of the sources of future energy and that energy is promising.

5) The current production capacity of energy does not have the ability to cover all the requirements in Libya. 
6) The growing demands for energy exceeds the current supply and the capacity of the power stations.

7) There is no legislation governing the legal supports and facilitate the spread of renewable energy in Libya.

8) There are no local or foreign investors in Libyan markets due to many reasons for example poor infrastructure and lack of suitable investment laws.

9) The prices of domestic energy are lower than the global ones. Therefore, any local investment would require much longer payback period.

\section{Recent political changes and renewable energy}

The research work for this paper has been performed prior and following the recent political changes in Libya. Most of the data was collected prior to the recent change in the government in 2011. The changes in the Libyan government after the data of this paper has been collected is considered as an important factor due to the potential possibility uncertainty in the strategic importance of renewable energy. At the time of writing this paper in 2012, the National Transitional Council (NTC) is leading Libya, a transitional government was formed immediately after the uprising on 17 of February 2011 and it is officially established on 5 March 2011. It was starting with 33 members on 27 February as the "legislative body", and then increased to 51 members $[12,13,14]$. The NTC has the responsibility for the provision of public services, law and system in Libya. The announcement of the new prime minister came on 23 October by NTC, the prime minister unveiled the interim government on 22 November 2011. In these interim governments, there is a member who is responsible for the electricity, water and renewable energy sector. This reveals the importance of renewable energy sector in the new Libyan governments and the continuity of the strategic importance of renewable energy. Therefore the authors have contacted some of the new Energy Policy Makers in the new and previous governments such as Head of Thermal Energy conversion Department in Centre for Solar Energy Research and Studies in previous government and Head of this centre in new ones, Dean Engineering faculty Garyounis University in Benghazi in previous government, Head of Department of Electrical and Electronics Engineering Al-Fatah University in Tripoli and others, they all expected that there will further and significant activity in the sector of renewable energy since the NTC is creating "Think Tank" for Libyan people ideas who will work for investigation of new revenue resources in Libya. 


\section{Discussion}

The continuous growth in energy demands is one of the important challenges facing the energy policy makers in Libya. Exploitation of renewable energy in Libya is becoming important to sustain people's lifestyle and sustaining energy resources. Libya, similar to other country, is seeking to boost its economy, increase and maintain its sources of income, encouraging investment, and creating new employment opportunities. In addition, the Libyan government started to address issues such as oil reserves and environmental pollution.

In relation to the availability of renewable energy, as discussed in this paper Libya has the resources to exceed, not only the local demand, but also significant part of the world energy demand. Investment in renewable energy could enhance the energy markets and secure long-term sustainable energy supplies. It can also provide commercially attractive options to meet specific needs for energy services, especially in remote areas.

The results in this paper illustrate the possibility of using wind power and solar energy exploitation in Libya and give much better picture in comparison to other countries. Unfortunately, the projects and jobs in this area are still insignificant and of experimental nature rather than of commercial form. The long sunny days, add an additional incentive factor to utilise this energy in large scale. It is important to state here that, even the standalone exploitation of solar energy on a micro-scale is technically and commercially possible. The load pattern shown in Figure 3 highlight the possibility of utilising solar energy for providing large sector of loads with almost fixed pattern regarding wind energy resources in Libya, there are several places known by their high wind speed and long windy times. Since 1940, the wind energy was utilised for water pumping in several oasis. The application of this technology has not been developed widely due to maintenance requirements. In Libya, the use of wind energy for electricity generation is still in its early days. In 2004, a project was contracted for installing 25 MW station as an experimental project. A project for collecting solar and wind energy data to provide fast access to reliable all over Libya is also been contracted for.

Currently, work is being performed for the installation of the wind farm with capacity of $60 \mathrm{MW}$ in Al-Ftih city, a good example of wind energy project. This farm is expected to be connected to the national grid and it is characterised by a high availability and excellent capacity factors. It is proposed that the agreement 
between the power output of this farm and the yearly load curve demonstrates that this farm can significantly participate in reducing the burden on the national grid in summer and winter, when the load reaches its peak. Primary and secondary research have shown that there is a high potentiality for wind energy resources and also revealed that several locations have average wind speed of about $5 \mathrm{~m} / \mathrm{s}$. The average wind speed at a forty meter height is between about 6 $7.5 \mathrm{~m} / \mathrm{s}$. It was measured in different places on the Libyan coast area such an Alftaih, Tukrah and Tubruq cities. So far, there is no plan to use wave, geothermal, biomass and energy from waste in Libya. There are several projects in different places, mainly close to the large cities with high population. The conducted interviews indicate the important of solar and wind energy in Libya. They also indicate there is political interest in the development of renewable.

\section{Conclusions}

From the literature review, field visits and secondary data it has been found that energy demand is increasing in Libya and that renewable energy could be the solution to cover some of this demand. Semi-structured interviews with 55 participants from the three main sectors in the field provided further details of the overall picture. It is evident, despite the recent political changes in Libya, that renewable energy is still strategically of high importance. Solar and wind energy are considered the main sources of renewable energy in addition to wave and tidal energy. There is a need to attract investors in renewable technologies by enhancing the infrastructure and the existing laws. Renewable energy technology is still within its early days in Libya. A clear strategy and time plan is still needed to take this sector forward particularly in relation to developing the skills and knowledge needed for installation and maintenance of such systems.

\section{Acknowledgement}

The authors would like to thank the Libyan Renewable Energy Authority and Centre for Solar Energy Research and Studies for providing some of the data used in this research work.

\section{References}

[1] Franz Tribe. Project Manager for the TRANS-CSP and the associated AQUACSP and MED-CSP report, Available on www.trecuk.org.uk/reports.htm ;2011[Accessed on 12.5.2011]. 
[2] Besisbo Faraj. Alternative energy sources and its role in the Production of electric power in Libya, Research Centre for Renewable Energy and Water Desalination - Tajoura; 2009.

[3] El-Osta W, Y Kalifa. Prospects of wind power plants in Libya: a case study, Renewable Energy 2003; 28: 363-371.

[4] El-Osta W. Evaluation of wind energy potential in Libya, Applied Energy, Special Proceedings 1995; Part II: 675-84.

[5] Mohammed B, Milad M. Wind Load Characteristics in Libya, world Academy of Science Engineering and Technology 2010; 63.

[6] Khalifa Y. Wind atlas for the coastal region of Libya, M.Sc. Dissertation, Mechanical Engineering Department, Alfateh University; March 1998.

[7] The Libyan Minster for Electricity, water, Gas and renewable Energy. Annual report 2009.

[8] Saleh I, Prospects of renewable energy in Libya: International symposium on Solar Physics and Solar Eclipses ( SPSE);2006.

[9] Graisa M, Al-Habaibeh A. An Investigation into current production challenges facing the Libyan cement industry and the need for innovation total productive maintenance (TPM) strategy: Journal of Manufacturing Technology Management 2011; 22: 541-558

[10] Graisa M. An Investigation into Need and Implementation of Total Productive Maintenance (TPM) in Libyan Cement Industry: Ph.D. thesis, Nottingham Trent University; 2011.

[11] Wind Atlas of Libya (version 1.0) for General Electricity Company of Libya and Renewable Energy Authority of Libya, work performed by CUBE Engineering GmbH March 2008.

[12] National Transitional Council. 19 March 2011.http://ntclibya.org/Arabic/firstannouncement/.Retrieved 25 March 2011.

[13] "The US recognises Libya's Transitional National Council". World Socialist Web Site. 20 July 2011. Http://www.wsws.org/articles/2011/jul2011/persj20.shtml.Retrieved 29 July 2011.

[14] "Introducing the Council | The Libyan Republic - The Interim Transitional National Council". National Transitional Council. http://ntclibya.org/english/about/. Retrieved 10 March 2011. 